\title{
An Evaluation of the Operations of Micro-credit Schemes in Poverty Alleviation of the Rural People in Northern Ghana - Case Study of Ghanaian-Danish Community Programme (GDCP)
}

\author{
Fuseini Mahama \\ Department of Accountancy, Bolgatanga Polytechnic, P. O. Box 767, Bolgatanga, \\ Upper East Region, Ghana.Email:fuzy73@yahoo.com
}

\begin{abstract}
The purpose of the study was to examine the sustainability of poverty alleviation activities, utilisation of the funds, the adequacy of credit given to the beneficiaries, level of savings and the degree of attention given to non-income-related issues. The study used questionnaires to capture responses of beneficiaries of the Ghanaian Danish Community Programme (GDCP) Micro-credit scheme as well as secondary data from the annual financial reports and statements of the scheme. The data were analysed with the ratios of the interest income to operational cost, operational cost to loans disbursement to arrive at operational sustainability and cost of money lent respectively. Tables and charts were used to provide the pictorial analysis of the interest income and the operational cost. The study revealed that the schemes were on course to sustainability but were characterized by high operational costs because of the nature of their activities. The study also revealed that the credit services provision had a positive impact on the beneficiaries overall lives, family nutrition and savings and there was evidence of proper utilisation of the funds. These merits were however, impeded by the inadequacy of the credits amount and limited attention given to non-income-related issues. Finally, the researcher made some recommendations and suggested steps for their implementation.
\end{abstract}

Keywords: Sustainability; Beneficiaries; Poverty alleviation; Savings; Impact; Micro-credit scheme

\section{Introduction}

\subsection{Background of the study}

Micro-finance which seems to provide a practical and workable tool to address the deep-seated challenges of poverty is fast growing as a major development strategy and international industry. The Micro-finance institutions (MFIs) are seen as one of the most efficient instruments in promoting economic development and fighting poverty in poorer countries. But the issue is the fulfillment of this promise as the development of micro-finance goals are often lost either due to technical and managerial problems in pursuit of financial sustainability or narrow focus on the poorest (Fisher and Sriram, 2002).

Within this context, United Nations Children's Fund (UNICEF) and Danish International Development Agency (DANIDA) integrate micro credit into their programmes in countries where lack of access to small loans is identified as an obstacle to the improvement of the situation of women and Children. In Ghana, as in many other countries, ensuring women's access to credit through microcredit schemes is a major component of poverty alleviation and women's empowerment strategies (Burra et al., 2005).

Before UNICEF for instance extend its support on micro credit programmes in the needy countries which Ghana is one, evaluation and impact assessments was conducted in two countries, Egypt and Viet Nam, which showed that micro credit can improve the well-being of the borrowers and that the impact is greatest when credit is combined with support for access to basic social services.

\subsection{Background of Ghanaian-Danish community programme}

The Ghanaian Danish Community Programme (GDCP) developed as a result of cooperation between the Ghanaian Danish Communities Association (GDCA) in Ghana established in 1986 and the Ghana Friendship Groups (GV) in Denmark. It is an integrated rural development programme operating in the Northern region of Ghana in the TolonKumbungu and Savelugu-Nanton districts and 
Tamale Rural. GDCP was the first of the GDCA programme to be established with funding from DANIDA received through GDCA's partner organisation GV in Denmark since 1986. It operates in four sectors and cooperation partners projects in addition to the Central administration which coordinates all the activities of GDCP. The sectors implement the programme activities in collaboration with the central administration and each other with each sector staffed and equipped to implement their specific activities. The sectors are Dagbon Ninneesim Karimzon (DNK), the Dagbon Adult Education Centre; Tinkpansi Lebgimsim (TL), Community Development/ Capacity Building; Simli Pong (SP), Micro-credit Schemes funded by DANIDA Simli Radio (SR), a community radio as well as cooperation partners such as EU, GDCAUNICEF Micro-credit Scheme, a cooperation partner project funded by UNICEF outside the GDCA cooperation with its Danish counterparts and Government of Ghana (GoG).

\subsection{Objectives of the study}

The general aim of this study is to explore and critically appraise the impact of Micro-credit provision to the welfare of the rural poor women. Many institutions provide micro-credit to the rural Poor, but the Ghanaian Danish Community Programme (GDCP) has been selected for this study because it is a major player in the enterprise of microcredit in Northern Ghana. The specific objectives of the study are:

i. To examine the sustainability of the Microfinance Institution and the beneficiaries. Whether the Institution recovers its operational cost including provision for inflation and also whether the beneficiaries make enough money to save towards becoming independent of the credit schemes.

ii. To examine the adequacy of sums given to beneficiaries and critically appraise the utilisation of micro credit funds to determine whether monies are used for and cover all the stated objectives

iii. To discover the problems encountered by microcredit schemes and the problems income enhancement will pose to women and children.

\section{Literature review}

\subsection{Brief history of Micro-credit}

The provision of micro-credit or small loans first arose in the mid 1970s. In those years, a new wave of micro-finance initiatives introduced many new innovations into the sector. Its allocations have increased dramatically in more recent years to especially women on whom the greatest burden of human deprivation, poverty, illiteracy and health related problems fall and also excluded from the formal banking sector. This ascendancy perhaps culminated into the first micro-credit summit that took place in Washington in 1997 where a pledge of about more than $\$ 20$ billion by donors and policy makers was made to support programmes. A general consensus at the summit posited that micro-credit benefits the poor and will reduce global poverty (Stacey, 2006 and Burra et al, 2005).

\subsection{Definition of Micro-credit}

According to Misra (2004), Micro-credit may be defined as a repeated credit provided in small measures to suit the recipient's requirements in a comfortable pace of repayment, and at an appropriate rate of interest. In another perspective, Micro-credit is small amounts of credit financing for either start up or on going operation or growth. These very small enterprises in this context are variously known as micro-businesses, or micro-enterprise (Wehrell et al., 2002).

\subsection{Operations of Micro-creditinstitutions}

Lack of access to credit has been a major problem in Africa, Latin America as well as Asia. In Africa for example, men and women entrepreneurs have traditionally relied on extended friends and family networks and rotating savings and credit associations (ROSCAs) for financial support. Entrepreneurs such as traders and retailers have been eligible for some credits once in business through suppliers with whom they have established long-term business relationships with (Rehman, 2002).

According to European Commission Report (2003), access to finance remains the main concern of microcredit applicants with the cost of that finance the second concern. The affordability of the weekly or monthly repayment is more directly important to them than the interest rate charged. The perception of micro-entrepreneurs about access to finance which is 
most important is quite different from the bigger companies.

\subsection{The role of donors}

Donors play a critical role in providing MicroCredit Schemes. Most donors recognise the diversity of stakeholders, that is regulators, policy-makers, bankers, NGOs etc. and their needs that require attention if markets for micro-finance are to develop. Their contribution in calling attention to the need for developing the competencies of different stakeholders is therefore significant (Fisher and Sriram, 2002). Increase in impact of micro-credit will not only require changes only at programme and NGO level, but crucially in donor policy (Mayoux, 1999). It is the case that internal cash flow difficulties arise in most donor supported organisations due to delays in the release of funds by the donors resulting in the inability of the implementers to abandon some activities (Adu-Anning et al, 2005).

\subsection{The role of government}

Conroy (2003) points out that, since the advent of the new order in Indonesia, the country's successive governments, acting through the central bank and a number of line departments, have supported activities categorised as micro-finance. This is in the right direction. Governments have a role to play in dedicating initiatives to financial sector development in some broader sense, or to nurturing particular micro-finance projects. However, according to CGAP report, (2006) government's involvement in micro-credit activities is disappointing. For instance, a research on UNDP project which was categorised according to the degree of government involvement indicate that out of 66 graded projects, 25 had substantial government involvement in their design and implementation, including direct retail delivery of micro-finance by the government in one case. Of 25 government involvement "intensive "projects, only one produced sustainable loan repayment and cost recovery. Almost all of UNDP's successes occurred in projects where government involvement was low.

\subsection{Impact of Micro-credit on cbild labour and education}

Children help their mothers in certain occupations by dealing with customers in petty shops, minding a grinding mill or painting/repairing the premises. A study conducted by SML found that children help out only after school and during holidays and therefore their education is not affected. In some cases, the children even force their mothers to learn how to write. By Implication, availability of micro-credit is not observed to increase paid child labour or withdrawal of children from school to augment family income. Children do help, but only after school hours (Burra, 2005).

\subsection{Becoming a cost effective MFI}

MFI must consistently evaluate whether or not it serves as many clients as possible with its resources at the lowest possible cost as the key to institutional financial self-sufficiency is cost. In practice, it is much more complex, particularly since backing sustainability and efficiency indicators is fairly new to MFIs and as a result "industry standard," which serve as guidelines in the business world, does not yet exist (Gibbons and Meehan, 2000).

\subsection{Sustainability}

According to Fisher and Sriram (2002), one of the main reasons for the popularity of micro-finance as apoverty alleviation tool is the belief that Microfinance Organisations can actually become "sustainable". There are many meanings to the term, ranging from the continuing ability to find and retain donors to the ability to cover all costs. This includes the cost of finance, the reduction in fund value caused by inflation and even a return on the investors' equity. But Mayaux (1999) indicates that the requirement of cutting cost of financial sustainability to a minimum has led many programmes to seriously cut complementary services. Anthropogenic Drivers on the Pressures on the Ramsar site of Sakumo Lagoon in Ghana.

According to Burra et al (2005), the primary thrust of SHARE Micro-Credit Limited (SML) is on financial sustainability which is efficiently ensured with overall repayment rate consistently at $100 \%$. A steadily increasing overall operational self-sufficiency stands at an impressive $104 \%$, but the percentage varies across branches as on November, 2001 indicating more than full cost coverage. It also takes in account inflation and the implied interest subsidy, as against actual cost of funds to SML to monitor its financial self-sufficiency in real terms that stands at $96 \%$. With the help of this ratios made the institution in remaining sustainable and accessing commercial funds from India and international sources for its operations. 


\subsection{Savings mobilization}

Burra et al (2005), considered savings as important for the viability of micro-credit beneficial groups. Mobilized savings can help the group to generate resources for internal rotation as loans, as well as to leverage credit from mainstream banking institutions. It can also serve as a tool for capital mobilization which enables members and groups to build capital for their own development, in a manner that suits their own needs. Each group has its own rules on how frequently savings are collected and the amount to be saved will depend on the terms and conditions of the credit delivered to the group.

\subsection{Implementation challenges in the Micro-credit sector}

Smith and Jain (in Dunford, 2001) pointed out that evidence of complementarily of micro-credit and education outcomes says little about the advantages of unifying their delivery within one organization. It indicates that society and business have different taste and what is good for the society may not be good for a service-delivery business and vice versa. An organization trying to operate simultaneously in two very different sectors of development activities such as providing loans and educating the beneficiaries about complementary breast feeding or personal hygiene through regular visit of say loans offices after the loan disbursement which may not necessarily to collect repayment may compromise its effectiveness and efficiency in one or both sectors (Fisher and Sriram, 2002).

\section{Methodology}

\subsection{Research design}

The methods employed, meant to recognise the operations of Micro-credit programme and the impact of the programme on both the Micro-credit institutions and the credit beneficiaries. The Microcredit- institutions are separate from the beneficiary communities. However, this allows interactions between the two to be conceptualised. The aim of the study was to access whether the micro-credit operation is making the people better or worse of practice. The researcher utilised a survey and document analysis methods to obtain both primary and secondary data, in the form of qualitative and quantitative data, from the Micro-credit institutions as well as the credit beneficiaries. The survey involved the use of questionnaires and telephone interviews to capture responses of beneficiaries of the Ghanaian Danish Community Programme (GDCP) Micro-credit scheme. Document analysiswas used to capture secondary data from the annual financial reports and statements of the scheme.

\subsection{Population and sampling method}

The population under study which consists of 13,112 women beneficiaries of the two micro-credit schemes under the administration of Ghanaian Danish Community Programme (GDCP) is large, making it impossible to interview the whole population. As a result of this constraint, a part of the population of the women beneficiaries referred to as sample was taken for study. The sampling process for this case study occurs on two levels: the case itself and the informants. GDCP Micro-credit schemes operating in Tamale Rural, Tolon-Kumbungu and Savelugu-Nanton districts were selected because they constitute the most convenient and accessible setting for the exploration of this research topic. The sample points were also drawn from the group beneficiaries who have received at least third loan cycles, because they should be able to express at least a fair opinion of the effect of the credit services on their lives (Daymon and Holloway, 2003). A sample size of 180 women from savings and credit associations (SCA) groups was selected from population of 13,112 for the study.

A non-probability sampling method, specifically quota sampling was used to put groups of the two schemes who were in their third to fifth loan cycles into two categories on the basis of not overlooking the influence of the girl child scholarship on the UNICEF sponsored scheme and subcategorised into the three districts. Each scheme had a quota of thirty women each from the three districts interviewed making the total 180 from the two schemes (Sapsford, 2007). The in-text references should be done sparingly so as not to give the impression that you don't have ideas of your own.

\subsection{Survey}

As indicated in the design, questionnaire was one of the methods used to collect data for the study. They were handed out to the loans officers who provided guidance in administering them to the members of the groups who were part of the sample (Sapsford, 2007). The secretaries to the groups then helped the individuals selected into the sample to complete the 
questionnaires. The study involved a total of 180 loans beneficiaries or programme participants who completed questionnaires. The participants were distributed as follows: 3 Districts - GDCA/UNICEF Programme - 90 and 3 Districts - Simli Pong Programme - 90. Response rate was 100\%. Indeed, all questionnaires were answered and returned. The telephone interview was successful. The other method used, telephone interviews, was used to collect the primary data from the Micro-credit institutions field staff who have knowledge of the operations in the schemes (Bryman and Bell, 2003).

\subsection{Document analysis}

Sustainability is very important for the operations of Micro-Credit Institutions. It is an area of interest to donors, government, practitioners and other stakeholders because it does not only guarantee the existence of the Institutions but also ensure continues credit services to the rural poor and also increase the coverage as the institution grows. What is crucial to the institution is to put in place good reporting system that conform with accounting practices of income and expenditure recognition, analysis of loans portfolio and losses.Vol.1, No.1, 2011] Anthropogenic Drivers on the Pressures on the

Table 1a

GDCA/UNICEF and Simli Pong Micro-credit schemes
Ramsar site of Sakumono Lagoon in Ghana

Regrettably, the records of the loans sector of this organisation under study were quite poor and not up to standard to enable the researcher to do the analysis up to the level of financial self sufficiency. There was absence of information on items such as various years' depreciation, market interest rate, inflation which comprises the adjustment to be made to come out with financial self sufficiency of the schemes for the various years. However, the data acquired was enough to calculate the scheme's operational sustainability. This part of the data analysis focused only on operational sustainability which shows the direction at which the operation of these Schemes are heading. It is important to draw the attention of readers to the fact that, the Provider of both schemes assumes responsibility of the cost of operations up to certain period before halting its support. In that case, they do not claim back the interest income from the loan fund. This adds up to the loan fund and all together will not be claimed back by the donors when they leave the MFIs to work on their own. While GDCA/UNICEF Credit Scheme received funding for the operational cost up to the end of 2004; Simli Pong received up to the end of 2005.It is also important to note that the cost of providing credit services to the rural poor is very high as compared to the cost of providing credit services to the urban

GDCA/UNICEF AND SIMLI PONG MICRO-CREDIT OPERATIONS FROM 2002 TO 2006

\begin{tabular}{llrrrrr}
\hline ITEM & & 2002 & 2003 & 2004 & 2005 & 2006 \\
\hline DISTRICT & GDCA/UNICEF & 2 & 2 & 2 & 3 & 3 \\
& SIMLIPONG & 3 & 3 & 3 & 3 & 3 \\
\hline TOTAL & GDCA/UNICEF & 372 & 372 & 372 & 398 & 398 \\
COMMUNITIES & SIMLIPONG & 372 & 372 & 372 & 372 & 372 \\
\hline OPERATING & GDCA/UNICEF & 55 & 100 & 100 & 126 & 126 \\
COMMUNITIES & SIMLIPONG & 102 & 102 & 116 & 116 & 125 \\
\hline TOTALSTAFF & GDCA/UNICEF & 10 & 10 & 10 & 13 & 14 \\
& SIMLIPONG & 5 & 5 & 6 & 8 & 8 \\
\hline FIELDSTAFF & GDCA/UNICEF & 6 & 5 & 5 & 8 & 9 \\
& SIMLIPONG & 4 & 4 & 4 & 5 & 5 \\
\hline GROUPS (SCAS) & GDCA/UNICEF & 70 & 123 & 123 & 199 & 271 \\
& SIMLIPONG & 121 & 129 & 138 & 141 & 219 \\
\hline MEMBERSHIP & GDCA/UNICEF & 1977 & 3015 & 3015 & 5363 & 7314 \\
& SIMLIPONG & 3146 & 3354 & 3588 & 4230 & 6572 \\
\hline
\end{tabular}

Source: GDCA/UNICEF AND Simli Pong Micro-Credit Schemes records for 2002, 2003, 2004, 2005 and 2006 


\section{Results and discussions}

The distribution of the loan beneficiaries and other programme participants for the two schemes GDCA/UNICEF and Simli Pong) are presented in Table 1. The scheme's interest income and the operational cost, which determines scheme's sustainability, are presented in Figures 1 (see data in Table in Appendix A). From the analysis, the build up of interest from both schemes has seen a significant and consistent increase even though the sustainability ratio rises and become constant on average. This is because of the continuous increase in the operational cost as a result of the presence of high inflation rate emanating from cost hikes in fuel and lubricant, maintenance cost and increase in staff salaries. The rate at which the operational cost increases also affected the cost per cedi lent to the clients. That is making operational sustainability of the Schemes almost constant after a sharp raised from 2002 to 2004 as depicted from the Figure 2.

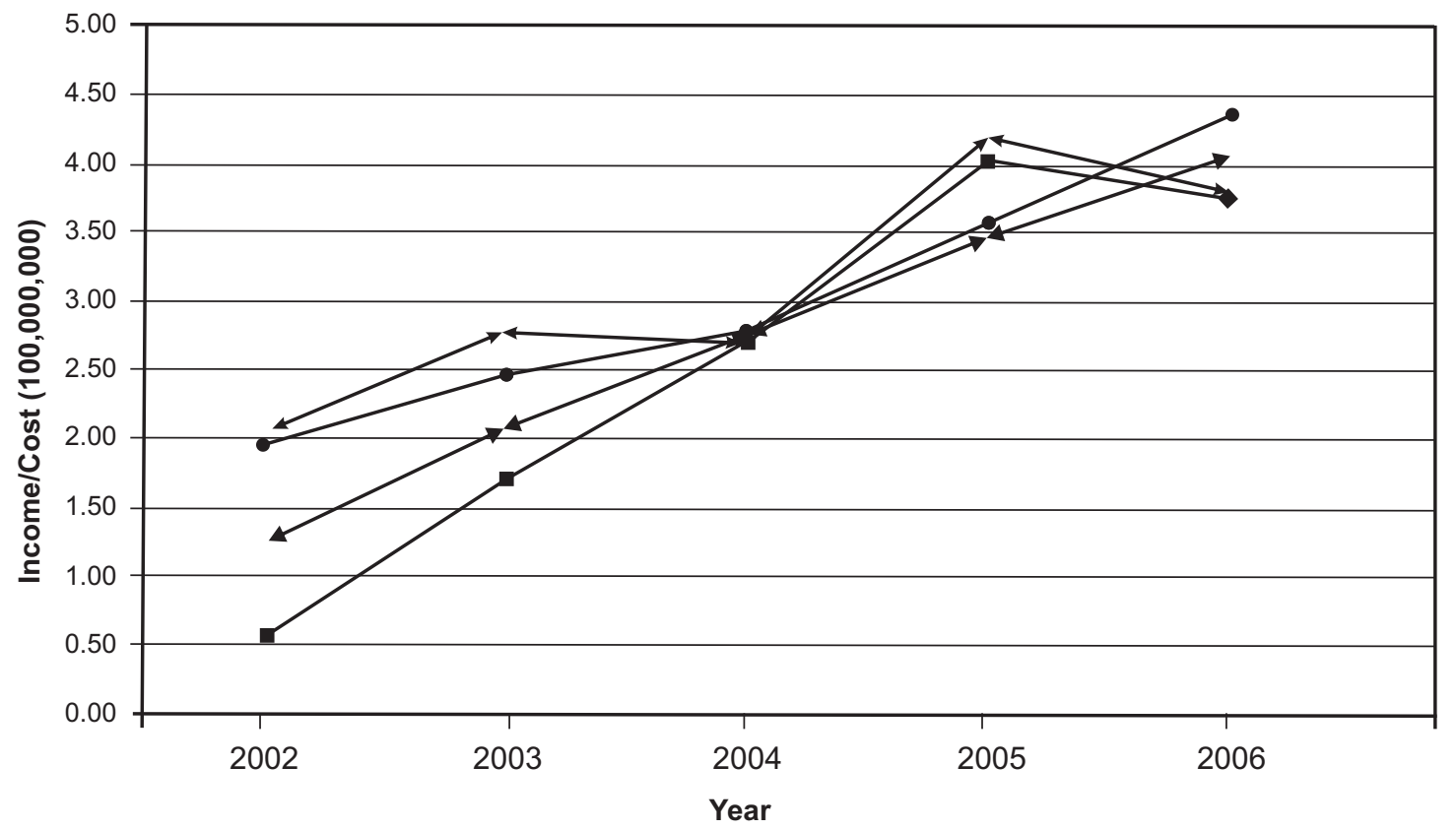

Fig. 1: Trend of interest income and operational cost for GDCA/UNICEF and SIMLIPONG from 2002 to 2006
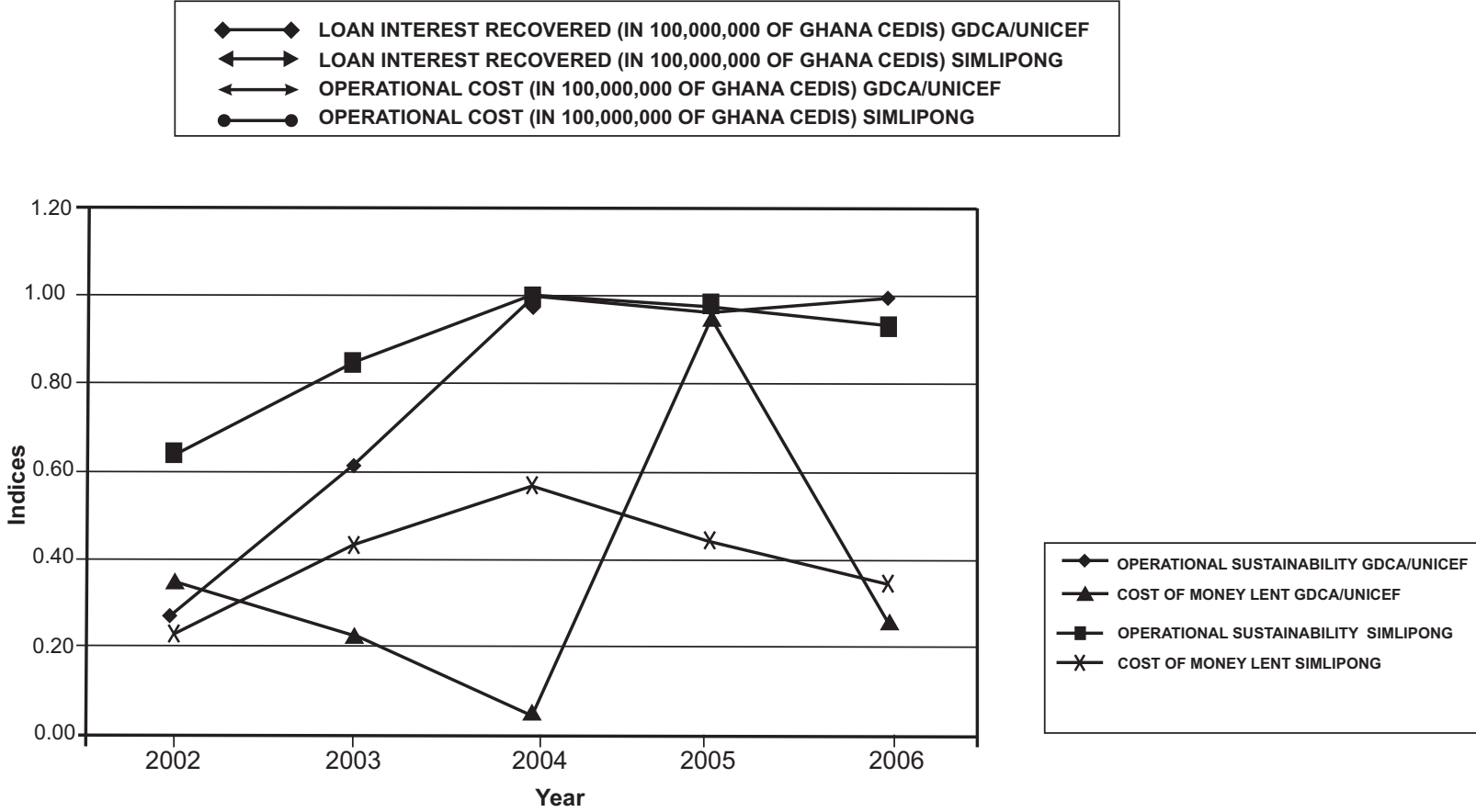

Fig. 2: Trend of operational sustainability and cost per money lent 


\subsection{Effect of the credit programme on participants}

This study focused on three basic possible social impacts of the credit services on participants. In this regard, the women who were sampled for this work responded to a set of questionnaires that were intended to capture their individual judgements on these three set of perspectives. These were their overall lives, their husbands' attitudes and the family nutrition status. These aspects of the study were judged to be of paramount importance because a success story means both donors and Micro Financiers have achieved their goals of providing credit to the rural poor women. Table 2 shows the participants' responses on the effect of the scheme on their overall lives, family nutrition and savings.

Table 2

Respondent overall life

\begin{tabular}{lcc}
\hline Effect & Number of Respondents & Percentages \\
\hline Negative & 0 & 0 \\
No effect & 3 & $2 \%$ \\
Positive & 95 & $53 \%$ \\
Very positive & 82 & $45 \%$ \\
\hline TOTAL & 180 & $100 \%$
\end{tabular}

Table 3

Effect of the credit services on the participants family nutrition

\begin{tabular}{lcc}
\hline Effect & $\begin{array}{c}\text { Number of } \\
\text { Respondents }\end{array}$ & Percentages \\
\hline Worse & 0 & 0 \\
No effect & 0 & 0 \\
Improved & 170 & $94 \%$ \\
Significantly improved & 10 & $6 \%$ \\
\hline TOTAL & $6 \%$ & $100 \%$
\end{tabular}

The data reveal very important information for donors and micro-financiers. $53 \%$ of the respondents were of the view that the micro-finance has had a positive impact on their lives.

The results from the monitored questionnaire showed that none of the respondents indicated that their participation in the credit programme has made their family nutritional status worse and or have no effect. But it rather marked a general improvement on the participants' family nutritional status with about $94 \%$ indicating that there was improvement on their family nutritional status and $6 \%$ said it had a significant improvement on their family nutritional status.

This study was also interested in investigating whether beneficiaries embarked on savings to enable them engage in investments and income generating activities after years of support from Micro-finance Institutions. To facilitate this, two forms of savings are enshrined in the rules and regulations of the Schemes. First, participants are expected to accept a compulsory savings initiative. To this end, a specific amount of money is taken out from each member's loan amount at the time the loans disbursements are taking place and paid back into the SCA's bank account. This serves as a form of security towards working from their savings. This policy is geared towards the sustainability of the Schemes' beneficiaries and their income generating activities.

Second, there is the voluntary savings scheme. The voluntary savings proceeds are also paid into the SCA's bank accounts and the amount paid is recorded in their pass books. The researchers examined the status of beneficiaries' savings towards working on their own in future. As a result of the compulsory savings facility, it was realised that all the 180 respondents do save. But the response from the participants and the Schemes field staff with regard to the credit worthiness of participants were mixed and controversial. About $73 \%$ of the 180 participants respondents indicated that their savings were enough for them to operate on their own and about $27 \%$ indicated that their savings were not enough to replace their loan capital.

However, the two field officers held a contrary view. Their response did not give an optimistic picture emphasising that the businesses operated by participants after five years assistance from the Schemes have had their business fortunes dwindling. They attribute this development to the size of the capital from their savings which they describe as small compared to the working capital they had from the credit services. They gave a reason that the amount given to them as loans was not enough to generate enough profit for them to embark on a significant savings drive.

\subsection{Challenges}

Figure 3 provides an outlook about the problems encountered by participants in the Credit Schemes. The responses from the questionnaire, point to three dimensional difficulties. Out of the 180 respondents, 
$44 \%$ identified lack of market demand for their products as their main problem. High operational cost was identified as the problem by $24 \%$ of respondents while $32 \%$ of those sampled regarded insufficient capital as their problem.

The field staff interviewed also gave an insight on the problems affecting participants. They posited that some of the beneficiaries need more than the amount credited to them, while others lack the business acumen to successfully manage the amounts of money given them. Incidentally, all participants in an SCA are given equal amounts of money which leads to the situation where some are given less than they need while others are given more than they can handle.

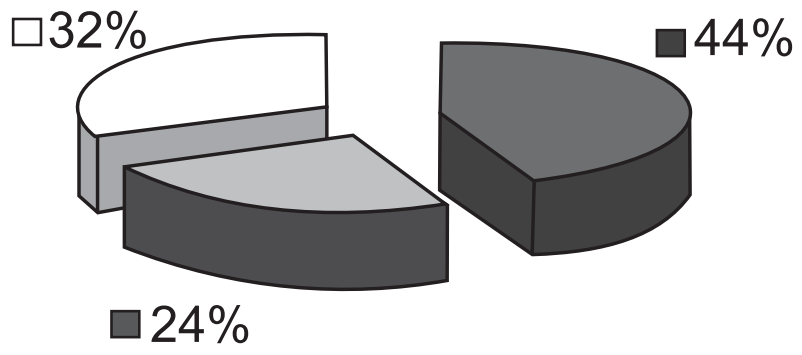

Marketing

High operational cost

Inadequate capital

Fig. 3: Outlook about the problems encountered by participants in the credit schemes.

\section{Summary of findings and conclusions}

GDCA/UNICEF and Simli Pong Micro-Credit Schemes credit programmes are geared towards achieving financial sustainability, improving the education of children as well as the status of family nutrition, health and sanitation. Also, it is their mission to make rural poor women economically active and to effectively participate in community development. To be able to subject the operations of the Scheme to a critical appraisal, it is imperative that an assessment of the sustainability of the scheme be made to take centre stage.

The evidence suggests that the GDCA/UNICEF and Simli Pong Credit Schemes have attained a level of an average sustainability of about $98 \%$ from 2004 to 2006. The issue of travelling long distance from community to community for loan disbursement, recovery and other issues on the bad roads linking the communities with motorbikes and vehicles which are not suitable for those roads are resulting into high maintenance and fuel cost. These are overshadowing the interest income and thereby driving back the operation sustainability index.

The reported results from the beneficiaries savings also provide evidence a sign of some level of sustainability. At least, their compulsory savings and the voluntary savings have added substance into their working capital even though it might not be enough to allow them operate at full capacity. In addition to those who were not into business are now being economically active. However, while participants are able to stay in business despite their inability to accumulate enough savings could be an area of interest for further research.

Table 4

Types of savings

\begin{tabular}{lcr}
\hline Savings & $\begin{array}{l}\text { Number of } \\
\text { Respondents }\end{array}$ & Percentages \\
\hline Compulsory savings only & 20 & $11 \%$ \\
Voluntary and compulsory & 160 & $89 \%$ \\
Savings & 180 & $1100 \%$
\end{tabular}

The results provided evidence of proper utilization of funds in accordance with the credit programme policies and procedures. Participants neither use loans on grain banking nor give it to their husbands to farm or perform funerals. Notwithstanding the fact that the analysis shows evidence of significant wide coverage of the schemes in terms of number of people and geographical area, the amount of money given as credit to some loans beneficiaries are inadequate. This has led to a limited impact on employment because of the small nature of the capital base. Those who have the potential to expand their businesses and to create more job avenues were severely constrained owing to fund inadequacies.

The results of this study clearly suggest that both Schemes have a serious problem of rising operational cost. This is hampering the future prospects of the Schemes. The fact that the income earned from interest does not fully cover the total operational cost means that other adjustments such as depreciation and inflation will have to be financed from the loan fund. Besides, the fund will be affected by inflation especially in Ghana where inflation rate is in double figures (about 11\%). 
Table 5

Three major problems

\begin{tabular}{lcc}
\hline Problem & $\begin{array}{l}\text { Number of } \\
\text { Respondents }\end{array}$ & Percentages \\
\hline Marketing & 79 & $44 \%$ \\
High operational cost & 44 & $24 \%$ \\
Inadequate capital & 57 & $32 \%$ \\
\hline TOTALS & 180 & $100 \%$
\end{tabular}

The researchers also found out that both Schemes have a problem of record keeping. The employees are unable to adequately document the financial transactions of the Scheme let alone prepare accurate financial reports which would reflect the state of affairs and direction of the Schemes. The current information systems of the Schemes for accounting and tracking lack the know-how unable to generate the standard reports needed for determining the future of the Schemes.

Even though the results produced from the study clearly show evidence of wide coverage of the credit services, is more loans oriented than education focused. Less attention is paid to the non-incomerelated issues and the loan officers are quick to admit that this lack of balanced approach has the potential to impede welfare improvement.

\section{Recommendations}

The operational cost of the Schemes needs to be controlled. For the Micro-Credit Schemes to play it role as a long term poverty reduction tool, it needs to be self sustainable and continue to provide credit services to the rural poor woman. The following are suggested steps by the researcher that can be used to minimise and control operational cost of the Schemes.

The amount given out as credit should be revised upwards so that those who are capable and need larger amount should be given. This will also increase the interest income at the same cost. Beside it may increase their profit margins. As a result they could save more and by the time the Scheme left them, they would have accumulated enough savings to guarantee continuous business operations.

The Scheme can also adopt a focused approach by increasing the loans beneficiaries in one community and concentrating on them and then moving gradually to the other communities rather trying to pick groups from all the communities at a go.

The researcher also recommends that the reporting system of the Micro-Credit Institutions needs to be improved. The Schemes need a quality reporting system that will enable them easily track current operations and also predict future scenarios. This can be done by providing the staff training and technical assistance.

\section{Purchasing modern accounting software}

The Scheme needs to be improved with regards to non-income related issues. Poverty is not only about lack of money, but also marginalisation and deprivation which are included in the education aspect of the credit programme and thus require sufficient attention. Government departments such as Cooperatives, Health and National Commission for Women and Development (NCWD) need to play their part because the loan officers are overstretched. The following measures are suggested by the researcher to deal with this issue. The Schemes should collaborate with other governmental and nongovernmental organizations such as National Health Department, National Commission on Children, Department of Cooperative, Department of Women and Ghana Education Service so that a concerted effort can be fashioned to fight the marginalisation and deprivation of the rural woman.

The Scheme should also seek governmental assistance through the District Assembly Common Fund so that fuel and lubricants and other operational cost can be subsidised.

\section{References}

Adu-Anning, C., Atuah, L., Duku, S.,Edusah, S. E., Fialor, S. C., and Sey, S., (2005). Micro-Credit as an Instrument to Promote Indigenous Food Resources in Ghana. The case of Abomosu snail Farmers in the Eastern Region. Working Document Series 123, Ghana, Kwame Nkrumah University of Science and Technology.

Al-Bagdadi, H. ,(2002). Micro-finance Association. The case of the Ghana Micro-finance Institutions Network (GHAMFIN). Deutsche Gesellschaft fur, Eschburn.

Benneh, N.Y., (2007). Bank Manager calls For MicroFinance Bank. Ghana Regional Neres of Friday, 22 June 2007. Available at: wrwre.ghanaweb.com. Accessed 23/06/07.

Brown, W. , and Nagarajan, G., (2000). Disaster Loan Funds for Micro-finance institutions: A Look at Emerging Experience. Development Alternative Inc,USA. 
Bryman, A. and Bell, E. ,(2003). Business Research Methods. Oxford University Press Inc., New York.

Burra, N. Deshmukh-Ranadive, J. and Murthy, R. K., (2005). Micro-Credit, Poverty and Empowerment. Linking the Triad. Sage Publication Ltd, London.

CGAP (1997). Introducing Savings and Micro-Credit Institutions: When and How. Focus Series No. 8. Accessed 25/06/07

Conroy, D. J., (2003). The Challenges of Micro-Financing in Southeast Asia. Institute of Southeast Asian Studies, Singapore

Daymon, C. ,and Holloway, I.,(2003). Qualitative Research Methods in Public Relations and Marketing Communications. Routledge, London.

de Vletter, F., (2001). Micro-Finance in Mozambique: Are Donors Promoting Regional Feminisation of Poverty? Zimbabwe. International Labour Organization ILO/SAMAT Discussion paper No. 16. Accessed 25/06/07

DeKlerk, T. ,and Rasulov, K., (2005). Evaluation MicroCredit programmes. UNDP, TAJIKISTAN. Accessed 25/06/07.

Dunford, C., (2001). Building Better Lives. Sustainable Integration of Micro-Finance with Education in Health, Family Planning and HIV/AIDS Prevention for the Poorest Entrepreneurs. Freedom from Hunger, USA. Accessed 22/06/07.

Dunford, C., (2003). Finance for the Poor. Adding Value to Micro-finance and to Public Health Education - At the same Time. A quarterly Nerwsletter of the Focal Point for Micro-finance. Vol. 4, No. 4. Accessed 22/06/07.

Dunford, C., (2006). Evidence of Micro-finance's Contribution to Achieving the Millennium Development Goals. Global Micro-Credit Summit Halifax ,Nova Scotia, Canada. Accessed 22/06/07

Erulkar, A., Bruce, J., Dondo, A., Sebstad, J., Matheka, J., Khan, A. B. and Gathuku, A. ,(2006). Tab and Reposition Youth (TRY). Providing Social Support, Saving, and Micro-credit Opportunities for Young Women in Areas with High HIV Prevalence. Population Council, Kenya. Accessed 25/06/07.

Erulkar, S.A., and Chong, E., (2005). Evaluation of a Savings and Micro-Credit. Programme for Vulnerable Young Women in Nairobia. Population council, Kenya. Accessed 25/06/07
European Commission., (2003). Micro-Credit for Small Businesses and Business Creation: Bridging a Market Gap. Enterprise publications. Accessed 22/06/07

Fisher, T. ,and Sriram, M. S., (2002). Beyond Micro-Credit. Putting Development Back into Micro-Finance. New Economics Foundation, London.

GDCA-UNICEF., Project Cooperation Agreement 2001 2005

Gibbons, S.D., and Meehan, W.J., (2000). The Micro-credit Summit's Challenge: Working Towards Institutional Financial Self-Sufficiency while Maintaining a Commitment to Serving the Poorest Families. MicroCredit Summit, Washington. Accessed 22/06/07

Hadi, A., (2001). Promoting Health Knowledge through Micro-Credit Programmes: Experience of BRAC in Bangladesh.Vol. 16, No. 3. Oxford University Press, Great Britain.

Historyof GDCA :www.ghanavenskabsgrupperne.dk/index.php?

Hossain, M. ,and Diaz, P. C., (1999). Reading the Poor with effective micro-credit: Evaluation of a Grameen Bank Replication in the Pbilippines. International Rice Research Institute (IRRI), Philippines.

Mayoux, L. ,(1999). From Access For Empowerment: Gender issues in Micro-Finance. CSD NGO Women's Caucus Position Paper for CSD-8, 2000,U.S.A. Accessed 22/06/07. Micro-Enterprise.,(2007). Best Practices (MBP) Rapid-Onset Natural Disaster Brief No. 8 Micro-finance Donors: Preparing For Natural Disaster. Accessed 22/06/07. Micro-finance. Wikipedia, the free encylopedia. Accessed 22/06/07.

Mishra, I., (2004). Micro-Credit for Macro Impact on Poverty. National Publishing House,India.

Rehman, N. ,(2002). Social Impact and Constraints of Micro-credit in the alleviation of Poverty: Qualitative study of Micro-Credit Programme Orangi Pilot Project. Orangi Charitable Trust,Karachi.

Sapsford, R. ,(2007). Survey Research. (2 ${ }^{\text {nd }}$ Edition). Sage Publications, London.

Saunders, M., Lewis, P. ,and Thornhill, A., (2007). Research Methods for Business Students. (4th Edn). Pearson Education Limited ,England. Simli Pong.,(2007). Business Plan 2007 - 2011

Stacey, P. (2006). Relations between Policy Assumptions and socio-economic organization. Copenhagen University , Denmark. 
The Consultative Group to Assist the Poor (CGAP)., (2006). Aid effectiveness in Micro-Finance: Evaluating Micro-Credit projects of the World Bank and the United Nations Development Programme. Focus Note No. 35. Accessed 22/06/07

Watson, A.A., and Dunford, C., (2006). From Micro finance to Macro-Change: Integrating Health Education and Micro-finance to Empower Women and Reduce Poverty. United Nations Population Fund and Washington, Micro-credit Summit Campaign ,New York. Accessed 22/06/07
Wehrell, R., Campbell, M., Cunningham, G., Mathie, M. A., and Lee, N. ,(2002). The Atlantic Micro-Credit Socio-Economic Impact Study. St. Francis Xavier University, Canada.

Williamson, H., (2007). Berlin proposes Africa MicroCredit fund. Financial Times Limited., Europe. Access 15/06/2007. 